\title{
Active Ageing: Using an ARCON Framework to Study U3A (University of the Third Age) in Australia
}

\author{
Ronald C. Beckett ${ }^{1}$ and Michael Jones ${ }^{2}$ \\ ${ }^{1}$ Centre for Industry and Innovation Studies, University of Western Sydney, Australia \\ rcbareinvent. net. au \\ ${ }^{2}$ School of Management and Marketing University of Wollongong, Australia \\ mjones@uow.edu.au
}

\begin{abstract}
There are more than 200 U3A groups in Australia where senior citizens collaborate to provide recreational learning opportunities to more than 60,000 other senior citizens. The movement continues to grow through the efforts of thousands of volunteers with very limited government support. We chose to use a collaborative network organisation modelling framework, ARCON, to both guide questions we asked in our research and to represent data from different instances in a consistent way. This provided a coherent view of the status quo, but supplementary questions were needed to consider the future viability of U3A groups. Spinoff network activities associated with some U3A groups were noted, suggesting the U3A model might be adapted for a variety of purposes. In such cases, it is hoped that the structured view provided by the ARCON framework might inform their design.
\end{abstract}

Keywords: Active Ageing, Collaborative Networks, ARCON, U3A, Volunteering.

\section{Introduction}

Many governments are supporting notions of active ageing in both the physical and intellectual sense to keep older members of the population healthy and stimulated. Individual intellectual stimulation may come from problem-solving, game-playing and lifelong learning. Community benefits [3] can be realised by accessing the collective experience of this older demographic, known as of the Third Age population, and providing stimulating learning opportunities [7]. In Australia, the primary government focus is on physical wellbeing, but large numbers of people (around 60,000) are engaged in local learning activities embracing an international initiative known as the University of the Third Age (U3A). These U3As operate with minimal, if any resources, yet they still achieve their stated goals. A question thus arises: how do they do it? Can an operating model be discerned? A recognised framework - ARCON - is used to characterise the U3A operations. This research extends a coherent understanding of how this arrangement works. We aim to see if the U3A example provides a substantive model for extension into other initiatives. 


\section{Background on the University of the Third Age (U3A)}

The University of the Third Age (U3A) began in 1973 when Professor Pierre Vellas organized a summer program for retired persons at the Universite des Sciences Socialies, Toulouse, France. The French model centred on a weekly public lecture on a major topic of concern for older persons. Supporting these were discussion groups, seminars, and recreational facilities, each taking advantage of the university facilities. Since 1973, the U3A concept has been implemented in many countries around the world [10]. China has the largest group. In 2002 there were reported to be 19,300 U3As and 1.81 million members [14].

Some countries have followed the French model. Others, including Australian U3A's, have followed a model that Midwinter [5] calls Tutorial Cooperatives of the Elderly. This latter derivative emerged in the UK in 1981 with 20 U3A's having 2,500 members being established in the first year. In this model, 'university' is given its original and intended meaning “... of people coming together to share and pursue learning in all its forms" [9]. The British model was first adapted by Peter Laslett - an academic from Cambridge University [15]. In 1981 he wrote the objects and principles of the British U3A [16]:

The pleasure of learning is a driving force in the work of U3As. U3As neither require nor award any qualifications. By sharing their learning, U3A members help one another to develop their knowledge, skills and experience. U3As arrange and support their own programmes as appropriate to their chosen learning activities. U3A members regard themselves as both learners and teachers.

\section{The Research Approach}

Data were collected from interviews with some Australian U3A group leaders and from web pages plus some site visits. One Australian researcher, Rick Swindell [14], has been engaged with Australian U3A initiatives for around twenty years. We have been able to draw heavily on his documented work and on interactions with him.

We have used a collaborative organisation model framework (ARCON) that emerged from a large European study $[1,2]$ to try and characterise the U3As in Australia. The ARCON framework assumes that both internal and external interactions influence the operation of a Collaborative Network Organisation (CNO). Each of these is characterised at three levels of detail as follows:

- Internal (endogenous) elements having structural (who is involved and how), componential (tangible/intangible assets utilized), functional (processes and procedures) and behavioural (governance rules and values) dimensions. Each of these dimensions has four subsidiary categories: the active entity, passive entities, action and concepts.

- External (exogenous) elements having market (who are the customers or potential beneficiaries), support (services provided by third parties), societal (the broader community) and constituency (potential new participants and supporters) dimensions. Each of these dimensions has three subsidiary categories: network identity, interaction parties and interaction types 
We developed four top-level questions related to each part of the model, with subsidiary questions stimulating discussion of further detail, again based on the model. These questions were:

- How can we broadly categorize this Cooperative? (Extent of collaboration, duration and focus)

- Why did the cooperative start and why are you involved? (Strategic intent and participant expectations)

- Tell us how this Cooperative works. Endogenous elements

- Tell us where this Cooperative fits in to the bigger picture. (Exogenous elements)

We found that whilst this provided information about the status quo, two supplementary questions were needed to explore the future prospects of the U3As:

- What helps this Cooperative to prosper and grow?

- What do you see as the potential risks to the continuing operation of the Cooperative?

\section{About U3A in Australia}

Australia adopted the British model, opening first in Melbourne in 1984, and then expanding throughout Australia. There are now over 211 U3A groups in Australia with 64,535 members [13]. According to a review by Swindell et al [8], the U3A groups in Australia range in size from a low of 24 members to a high of 5500 members (Sydney U3A). Nine groups have more than 1000 members. The median U3A Australian membership is 414. Australian U3As do not appear to limit membership numbers. The number of males participating has increased in recent years. The female/male ratio is now about 3:1. Providing intellectually stimulating opportunities and social networking are seen as the two major accomplishments of U3As. There is reported to be strong support for continuation of a laissez faire approach to teaching and learning in which course leaders come from any walk in life and teach in their preferred style. There was little enthusiasm for academic courses. Teaching takes place in any suitable community venue like rented premises, free or subsidized community facilities or private homes. Favoured ways of maintaining course quality were feedback from participants and "market forces".

\subsection{The Local U3A Groups}

Local U3A groups are set up as self-standing entities, generally registered as unincorporated not-for-profit associations with a volunteer governing board and administrative staff. Most office bearers have a professional or business background. Volunteers may be teachers on one occasion and learners on another, but the focus is on sharing knowledge. Drawing on experience gained over many years, course delivery is commonly via a series of two-hour face-to-face sessions. Teaching facilities may be provided by other charitable organisations or by local government. Some U3As ask members to commit to a few hours of voluntary work each month on joining. One large U3A (ACT) reported attracting a healthy flow of recent retirees as 
well as retaining a relatively high proportion of old members. One quarter of its 3700 members were aged 65 or less; 14\% were aged 80 and older. The success or failure of a U3A group is strongly related to the skills and energy of its leadership [13].

Our interviews suggested that whilst many seniors groups tend towards the social rather than the intellectual needs of older people, U3A attracts people who want more and who in many instances can give more, because of their past experience as teachers, lecturers, historians, lawyers etc, as well as other walks of life. Its members have an enthusiasm for lifelong learning, and can share experience and knowledge as well as learn new things themselves. ---- Put simply, U3A is an educational movement, not just a senior's organization (a regional U3A leader). A scan of contact data of 160 local groups in two States indicated about $60 \%$ of U3A groups maintain a website. Swindell et al [13] report the following: more than a third of U3As use the Internet as a teaching/learning resource.

\subsection{Regional Coordination Groups}

The largest regional group, U3A Network Victoria, represents 97 U3As having about 25,000 members. It is recognized by the Adult, Community and Further Education Board of Victoria as an education Peak Body. This makes it eligible for some funding consideration. Such funds are used to help engage a small number of paid employees. Governance is through a council of nominated representatives from members and an elected executive committee. Further sub-committees are instituted in the areas of finance, publicity and promotion. Its role is to promote the U3A movement, fostering the creation of new U3As and the further development of existing U3As; serving as a reference body, acting as a central resource facility, providing publicity, promotion and profile to the general public and to government and other public bodies. Information is disseminated through a Quarterly newsletter, a website and meetings of member representatives. The newsletter also presents opportunities available across local groups, such as special interest study tours.

\subsection{U3A on Line}

The Following observations have been provided by Rick Swindell [14]: U3A Online, was set up in 1998 with a global focus from the outset. The administration and teaching in U3A Online is carried out by about 100 volunteers. Governance and administration occurs through regular virtual meetings. Discussion and voting takes place by electronic forum, email and Skype. It is commonplace for the majority of volunteers to work closely together for many years but never physically meet.

Since 2002, Griffith University in Brisbane, Australia has hosted the entire operation free of charge on university servers, as part of its service to the wider community. In 201139 courses were available to U3A Online members with others in various stages of completion. For an additional fee, a further 13 courses are available to members through a cooperative arrangement with the Third Age Trust in the UK, which has provided online courses for its UK members since 2000. Depending on the availability of volunteer tutors, members may opt to pay an additional fee to join tutor-led discussions, during which participants interact with the leader and with others in the course by online forum and email. Site licenses are an additional service 
available to any U3A-style organization in any country. The course notes have all been written and illustrated by expert volunteers in their fields and in some cases these run to more than 100 pages when printed. All courses and resources are in English. In 2008, about 35\% of Australian U3As were using on-line courses.

\section{Discussion}

We now consider the characteristics of the U3As studied in relation to attributes of the ARCON reference framework. The on-line and local Australian U3As are coalitions of individuals with a common interest in learning. They regard themselves as both learners and teachers with an emphasis on collaboration. In the ARCON framework this extent of collaboration implies - communication \& exchange for mutual benefit plus a complementarity of goals - aligning activities for mutual benefit, plus compatible goals with individuals working apart (with some coordination) plus having joint goals, joint identities and joint responsibilities (creating together) and (participant) teams. This describes U3A working arrangements quite well. The regional U3A's are coalitions of organisations that deliver services with an emphasis on cooperation. In the ARCON model, this implies - communication \& exchange for mutual benefit plus a complementarity of goals - aligning activities for mutual benefit, plus compatible goals with individuals working apart (with some coordination). Again a good description. The common themes are communications, exchange for mutual benefit and complementarity of goals. The primary communication tools are newsletters and word-of-mouth, but internet use is increasing. U3As are long-term strategic networks consistent with the ARCON definition of a professional virtual community: is an alliance of professional individuals, and provides an environment to facilitate the agile and fluid formation of virtual teams. This describes the local $\mathrm{U} 3 \mathrm{~A}$ arrangements for establishing and running courses quite well. Virtual teams are established at the regional level for a variety of purposes.

The ARCON framework requirements for collaboration include a number of things. A clear purpose - This is well enunciated in the British U3A model that is incorporated in the individual Australian U3A formation documents, as are some basic requirements like processes for defining structures and policies. At the personal level, the primary interest is in recreational learning (as compared with vocational learning). However, some individuals participate in courses for a specific purpose, such as learning a language prior to visiting a foreign country or learning about IT to be able to use e-commerce or to communicate with grandchildren. One of the preconditions for collaboration in the ARCON model is that parties must know each other's competencies. In the U3A case, this seems to have been established by social networking prior to formation and subsequently during operation as people volunteer to undertake different tasks. Another ARCON requirement is for a collaboration space. For most U3As this is a physical space, but both the U3A NSW regional group and the on-line U3A group seem to function quite well in a virtual space. Other ARCON requirements are concerned with ownership and sharing of resources and of equitable distributions of commitments and rewards. The U3As own almost no resources except for modest member funds, as they hire facilities or have them provided by external supporters. Most of the work is done by volunteers, where doing a job well is its own reward. However Mitchell et al [11] reported other benefits from 
a survey of 975 members - that members of U3A had better-than-average general, physical and mental health, and that membership of U3A can, even in the very elderly, assist in conferring a much more positive perception of well-being.

The ARCON framework provides a tructural view that helps us understand how Australian U3As work, but not why they are sustainable or why they continue to grow. It has been observed that the individual U3As value their independence. A survey of 122 U3As [13] reported that most would prefer to decline external assistance due to potential loss of autonomy (60\%), increased bureaucracy (30\%) and contrary to self-help ethos $(25 \%)$. Important considerations for the immediate future were seen as maintaining or increasing membership, offering a wider range of courses, and seeking more permanent accommodation. When asked about the longerterm future, the most strongly supported suggestions were: 1) technical demands on the Third Age population will increase, 2) there is an expectation that retirees will need to do more to support themselves, and 3) a national communication network will assist local U3As to better meet the needs of a changing society. Anecdotal evidence also suggests that U3As need to become far more professional and organised to attract baby boomers or they could slip into quiescence.

Most data used in developing the ARCON framework related to collaboration between a modest number of enterprises, whereas the power behind the U3A network comes from a large number of individual volunteers. 60,000+ participants in Australia might sound like a lot but it represents only $0.85 \%$ of the total demographic group that could potentially participate, suggesting that these people have something special that drives them. It is suggested that this is an attribute of all successful collaborative network organizations - there is something special about the core participants.

We wanted to explore U3A operations as a potential model for other activities. Along the way, some spinoff activities were identified, suggesting this is a practical proposition. Timewitnesses [12] is an example of the Internet opening up cooperative ventures for U3A members around the world. Timewitnesses is a "living archive" which allows people from any country who have childhood or adult memories of World War II, to preserve their stories for everyone. Many of the stories have been translated into German and French and in a number of cases school children assisted with the translations. [12]

U3A Online has sponsored a number of research/development studies of U3A operations that have been carried out in association with appropriately trained member researchers. The fundamental strength of the constituency research approach is that it entails research "with" rather than research "on" older people. The difference between "with" and "on" may not matter too much in large scale tick-abox surveys. However, if much richer findings are needed, these are more likely to arise from interviews carried out by peers who are perceived to have primary empathy with the participants, rather than by younger researchers whose appearance, manner of dress, language, general persona, and time constraints may create barriers to in-depth communication [6]. "A voice worth listening to" is an example of a novel constituency research project undertaken exclusively by third agers. In this project a retired journalist visited and interviewed people aged 80 and older in Australia and New Zealand who were continuing to do remarkable things within their communities. The purpose of the research was to debunk the ageist and damaging mindset that advanced chronological age inevitably implies that an older person has become a burden on society. The lead researcher was in her mid 70s. 


\section{Concluding Remarks}

This paper makes two contributions to the literature. Firstly, it describes an instance of a self-supporting active ageing network driven by users for users. Secondly, it explores the utility of a collaborative network model, ARCON, in helping to understand the characteristics of the case study network.

U3As in Australia are formed by groups of individuals in local communities, not organisations like many collaborative network organisations. They want a stimulating, participative recreational learning network for seniors, not a senior's social network that may provide learning. Both conventional and on-line learning modes are available. The focus is on long-term collaboration. Whilst each group operates as a separate entity, most choose to contribute to a regional virtual or physical office to cooperate in acquiring services as a group, sharing information on courses, interacting with governments and facilitating membership growth. Some coherent structures are provided in that each local group is formally constituted, generally as a not-for-profit unincorporated association, and its constitution includes common foundation principles from a British model. Some spin-off activities that contribute to the broader community were also observed, indicating the practicality of alternative applications of the U3A model, which is similar to a professional virtual community arrangement.

The ARCON framework provided a good foundation for checking that the right questions were asked about the extent and style of collaboration in the research phase and for positioning U3A operations in the very broad spectrum of Collaborative Network Organisation possibilities during analysis. It was found however that supplementary questions about the future directions and possible risks to U3A sustainability were needed in the case of this long-term collaboration. Parallel consideration of human factors (individual actor attitudes and contributions) linked to literature on volunteering was also necessary. The real U3A drivers are the thousands of volunteer administrators and tutors who share their time and knowledge in an environment where these contributions are valued. It is reported that both this group and the student group experience increased self-esteem and feelings of wellbeing. There is some evidence that networking within and between U3As can provide a foundation for knowledge capture and research activities. There is also anecdotal evidence of entrepreneurial behaviour in establishing courses and marketing a U3A that will be the subject of a follow-on study.

\section{References}

1. Camarinha-Matos, L.M., Afsarmanesh, H., Ollus, M.: ECOLEAD: A holostic approach to creation and management of virtual organizations. In: Camarinha-Matos, L.M., Afsarmanesh, H., Ortiz (eds.) Collaborative Networks and their Breeding Environments, pp. 3-16 (2005) ISBN 0-378-28259-0

2. Camarinha-Matos, L.M., Afsarmanesh, H., Ermilova, E., Ferrada, K.A., Jarimo, T.: ARCON reference models for collaborative networks. In: Camarinha-Matos, L.M., Afsarmanesh, H. (eds.) Collaborative Networks: Reference Modeling. Springer, New York (2008)

3. Healy, J.: The Benefits of an Ageing Population The Australia Institute (2004) ISSN 13225421 
4. Midwinter, E.: How many people are there in the third age. Ageing and Society 25, 9-18 (2005)

5. Midwinter, E.: The University of the Third Age in Britain. Higher Education Quarterly 38, 9-15 (1983)

6. Mayhew, C., Swindell, R.: Some Pleasures and Pitfalls of Working with Older Research Assistants. Australasian Journal on Ageing 15, 164-166 (1996)

7. Clarke, A., Warren, L.: Hopes, fears and expectations about the future: what do older people's stories tell us about active ageing? Ageing and Society 27, 465-488 (2007)

8. Swindell, R.: Characteristics and Aspirations of older learners in an Australian University of the Third Age Program: Part 1 - Survey Results. Educational Gerontology 16(1), 1-13 (1990)

9. U3A Trust, UK, http: / / u3a.org.uk/ (last accessed March 31, 2011)

10. World U3A, http: / / worldu3a.org/ (last accessed March 31, 2011)

11. Mitchell, R.A., Legge, V., Sinclair-Legge, G.: Membership of University of the Third Age and perceived well-being. Disability and Rehabilitation 19(6), 242-248 (1997)

12. Timewitness, http: / / timewi tnesses . org / (last accessed March 31, 2011)

13. Swindell, R.F., Vassella, K., Morgan, L., Sayer, T., Browne, R., Stewart, J., Waddington, J., White, B.: U3As in Australia and New Zealand 2008: The Successful Ageing organizations. Griffith University (2009),

http://www3.griffith.edu.au/03/u3a/u3aonline/ (last accessed March 31, 2011)

14. Swindell, R.: Successful Ageing and International Approaches to Later Life Learning (in publication)

15. Peter Laslett, http://courses.u3a.org.uk/about-u3a/history-ofu3a.html ? start=1 (last accessed March 31, 2011)

16. Objects and Principles,

http: / /www.u3a.org.uk/index.php?option=com_content\&task=view\& id=160\&Itemid=52 (last accessed March 31, 2011) 